\title{
トキサフェン及びマイレックスによる 日本近海鯨類の污染とその蓄積特性
}

\author{
今西 克也 ${ }^{1)}$, 川上 学1)，島田あずさ11)，木村 義孝 ${ }^{2)}$, 近石 一弘 ${ }^{1)}$, \\ 村上 雅志 ${ }^{2)}$, 梶原 夏子 ${ }^{3)}$, 山田 格 ${ }^{4}$, 田辺 信介 ${ }^{3)}$ \\ ${ }^{1)}$ (株)住化分析センター 愛媛事業所（７７92-0003 愛媛県新居浜市新田町3-1-39） \\ ${ }^{2)}$ (株)住化分析センター 環境技術センター（テ299-0266 千葉県袖ヶ浦市北袖9-1） \\ 3)愛媛大学沿岸環境科学研究センター（テ790-8577 愛媛県松山市文京町2-5) \\ ${ }^{4}$ 国立科学博物館（テ169-0073 東京都新宿区百人町3-23-1）
}

[平成17年 3 月 9 日受理］

\section{Toxaphene and Mirex Residues in Cetaceans from Japanese Waters}

\author{
Katsuya IMANISHI ${ }^{1)}$, Manabu KAWAKAMI ${ }^{1}$, Azusa SHIMADA ${ }^{1)}$, Yoshitaka KIMURA ${ }^{2)}$, \\ Kazuhiro CHIKAISHI ${ }^{1}$, Masashi MURAKAMI"), Natsuko KAJIWARA ${ }^{3)}$, \\ Tadasu YAMADA ${ }^{4)}$ and Shinsuke TANABE $^{3)}$ \\ ${ }^{1)}$ Sumika Chemical Analysis Service, LTD., Ehime Laboratory \\ (3-1-39 Shinden, Niihama, Ehime 792-0003) \\ ${ }^{2)}$ Sumika Chemical Analysis Service, LTD., Environmental Technology Center \\ (9-1 Kitasode, Sodegaura, Chiba 299-0266) \\ ${ }^{3)}$ Center for Marine Environmental Studies (CMES), Ehime University \\ (2-5 Bunkyo, Matsuyama, Ehime 790-8577) \\ ${ }^{4)}$ National Science Museum \\ (3-23-1 Hyakunin, Shinjuku, Tokyo 169-0073)
}

[Received March 9, 2005]

\begin{abstract}
Summary
Toxaphene and mirex were detected in all the blubber samples of cetaceans collected from Japanese waters during 1998 2001 with concentrations ranging from 140 to 6,700 ng/g lipid wt and 2 to $170 \mathrm{ng} / \mathrm{g}$ lipid wt, respectively. To our knowledge, this is the first comprehensive study to detect these pesticides in the biological specimens from Asian waters including Japan where these chemicals have never been registered. Concentrations of toxaphene and mirex in species migrating to the offshore areas of North Pacific, Sea of Okhotsk and the Japan Sea were much higher than those in Japanese coastal species, indicating that considerable amount of these pesticides have been transported to the environment around Japan via atmosphere, a phenomenon common for persistent organic pollutants (POPs). Additionally, this result may confirm that these pesticides were not used in Japan in the past.
\end{abstract}

Key words: Toxaphene, Mirex, Marine Mammal, Aerial Transport, Wide Range of Pollution 


\section{1. はじめに}

トキサフェンおよびマイレックスは難分解性，高蓄積 性, 揮散移動性及び蓄積に伴う生態毒性の 4 つの特徴を 有する化学物質として12種類の残留性有機污染物質 （POPs）に含まれている。2001年 5 月に地球環境的視野 からそ机らの廃絶，削減等を目的とした「残留性有機污 染物質に関するストックホルム条約」(POPs 条約) が採 択され，日本も2002年 8 月に批准した。2004年 5 月に条 約が発効され, 今後, 地球規模での污染実態や発生源, 移動性，蓄積性，毒性に関する知見を集積・検証するこ とが求められている。環境省は条約に対応すべく, POPs モニタリング調査を 2002 年度（トキサフェンおよ びマイレックスは2003年度) から開始している。

トキサフェンは, 植物から得られる $\alpha$-ピネン由来の カンフェンを塩素化して合成される多成分混合体の総称 である。置換塩素の位置と数により, 理論的には 3 万種 以上の異性体が存在するが ${ }^{1}$, 現在までのところ, 単離・ 同定されているのは約50成分にすぎない2)。1940年代後 半に米国で製造が開始され3)，綿花用害虫防除剤を主に， 大豆や落花生等の害虫防除剂, 家畜の疥痽治療薬, 湖沼 における外来魚の駆除戍として広く使用された に1970年代前半にDDTの使用が禁止されると，その代 替物質としての利用が急速に拡大した ${ }^{3.6)}$ 。トキサフェン を多用した国は米国，ついで旧ソビエト連邦やメキシ コ，ブラジル，コロンビア等で，1950年から1993年の間 の世界の総使用量はDDTの半分に相当する133万トンと 見積もられている7.100。その後, トキサフェンの毒性や環

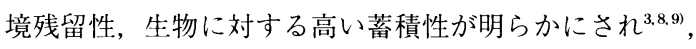
米国では1982年にその使用が禁止された3.10)。カナダや ヨーロッパ諸国等も米国に続き規制を開始したが3.10), メキシコや旧ソビエト連邦，アルゼンチン，東欧諸国の 一部では, 1992年の段階で継続的な使用が報告されてい る7。これまでにトキサフェンは様々な環境媒体から検 出されている(11)。その製剤は複雑な混合物であるが, 環 境中から検出される残留物は限られた成分のみで，媒体 によって検出成分，組成が異なっている. キサフェンは大気輸送され, 使用実績のない地域の生物 に高濃度で蓄積していることが報告されている ${ }^{15-21) 。}$

マイレックスは塩素が12個置換した縮環化合物で, 卜 キサフェンと異なり単一成分である。1950年代後半から 米国で製造が開始され，主にヒアリ駆除等の殺虫剤とし て北米南部, 南米拉よび南アフリカで大量に使用され

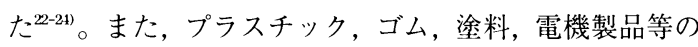

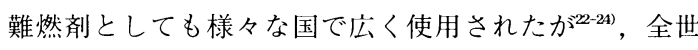
界の使用地域及び使用量の詳細は不明である。トキサ フェンと同様にその毒性や環境残留性が明らかとなり， 1977年にカナダで，1978年に米国で，その後ほとんどの
国々で使用禁止となった2.23)。しかしながらマイレック スは化学的に安定で, 微生物による分解を受けにくいた $\bigotimes^{22)}$, 五大湖では今後数 100 年に渡って環境中に残留す ると推定されている ${ }^{25}$ 。

トキサフェンやマイレックスに関する研究は欧米を中 心に行われており，アジアを対象としたものは乏しい。 これら二種類の有機塩素系農薬は大気を経由した移動拡 散が指摘されているにも関わらず，日本ではトキサフェ ン及びマイレックスの製造ならびに農薬としての登録実 績がないこと等から，15年以上前に環境庁等 ${ }^{26,27) に よ る ~}$ 断片的な調查例があるのみで，これまで本格的な環境污 染の実態調査は実施されなかった。そこで本研究では, 生物の中でもこれら脂溶性化学物質を高濃縮することが 知られる鯨類を対象に，日本近海のトキサフェンおよび マイレックス污染の実態とそれらの蓄積特性の解明を試 みた。

\section{2. 試料と方法}

\section{1 試料}

1998年から2001年にかけて日本沿岸に漂着または近海 で捕獲した鯨類25検体の脂皮を化学分析に供試した。試 料の詳細及び採取場所を Table 1 および Fig. 1 に示す。 北海道周辺海域, 日本海, 太平洋, 瀬戸内海の各海域か ら沿岸性鯨類 2 種: スナメリ (Finless porpoise, Neophocaena phocoenoides), ネズミイルカ (Harbor porpoise, Phocoena phocoena), 外洋性鯨類 2 種：イシイ ルカ (Dall's porpoise, Phocoenoides dalli), カマイルカ (Pacific white-sided dolphin, Lagenorhynchus obliquidens), 深海が主な拱餌域とされている鯨類 1 種：オウギハクジ ラ (Stejneger's beaked whale, Mesoprodon stejnegeri) の 合計 5 種の鯨類を対象にした。イシイルカは, 日本海を 回遊ルートに含むイシイルカ型（dalli-type）と太平洋側 に生息するリクゼンイルカ型（truei-type）の 2 つの個体 群から試料を得た。いずれの鯨類も歯鯨類に属し, 主な 餌生物はイカ類, 小型魚類 (イワシ, ニシン等) である。 採取した試料は分析時までー $20^{\circ} \mathrm{C}$ で保存した。

\section{2 化学分析}

\section{2.1 試薬}

使用した試薬を以下に示す。 トキサフェン標準品：LGC Promochem 製 マイレックス標準品: 和光純薬製

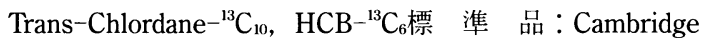
Isotope Laboratories 製

2, 2', 4, 5, 5'-Pentachloro $\left[{ }^{13} \mathrm{C}_{12}\right]$ biphenyl, 2, 2', 3, 3', 4, 4', 5 -Heptachloro $\left[{ }^{13} \mathrm{C}_{12}\right]$ biphenyl 標準品: Wellington Laboratories 製 


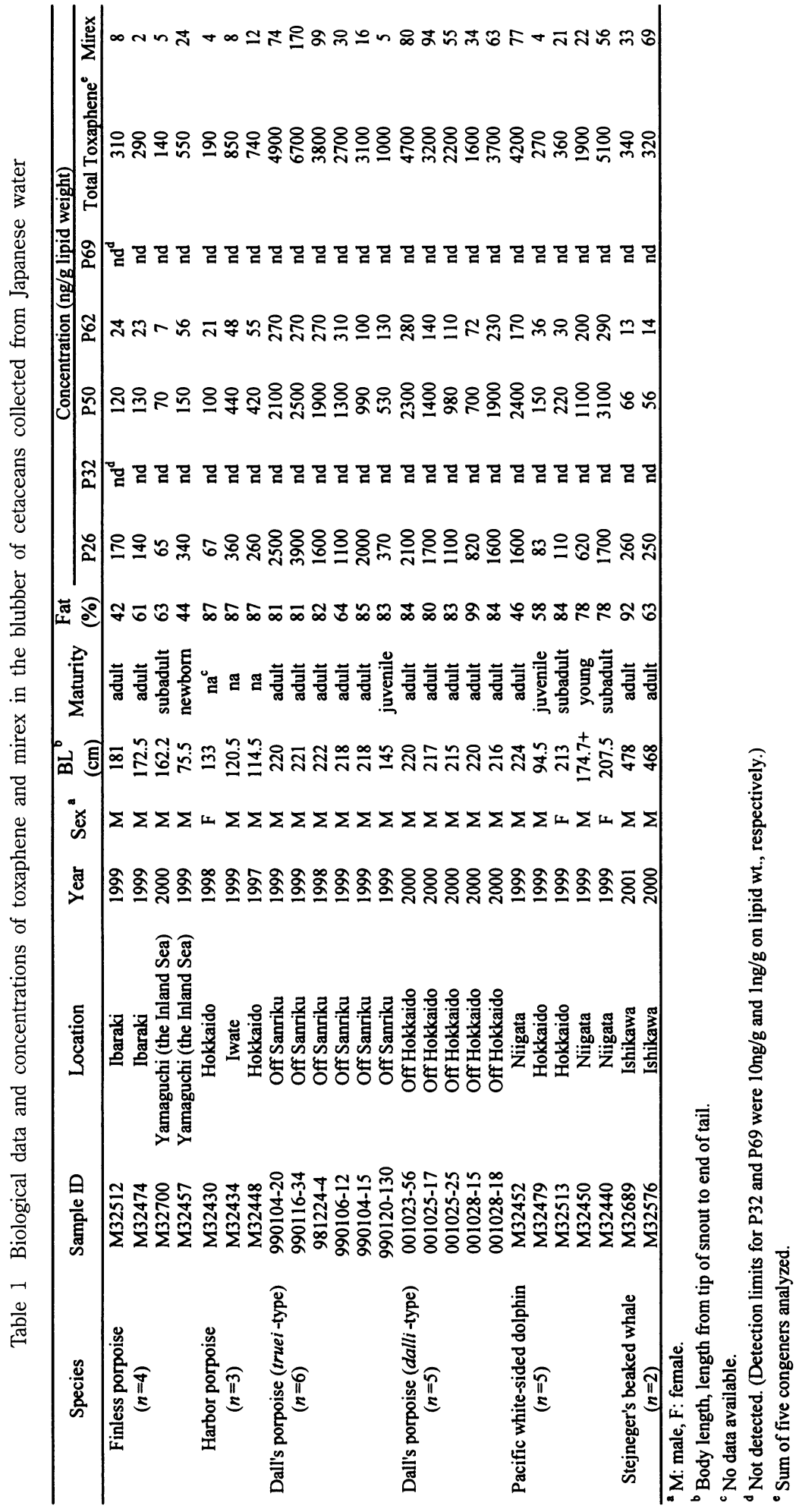




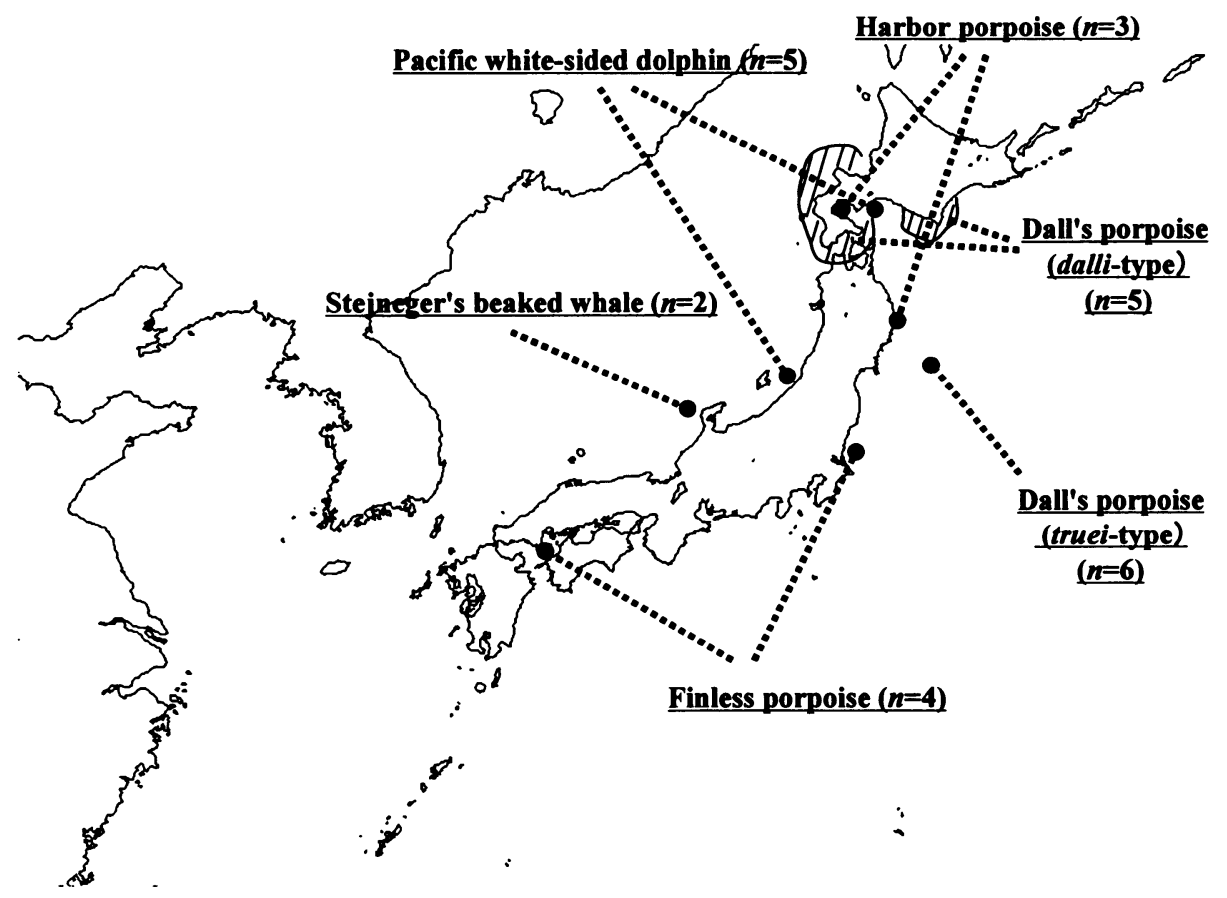

Fig. 1 Map showing sampling locations of cetaceans analyzed in this study

アセトン, ヘキサン, ジエチルエーテル：和光純薬製 (残留農薬分析用 (5000倍濃縮保証品))

アセトニトリル, ジクロロメタン, エタノール：和光純 薬製 (残留農薬分析用 (300倍濃縮保証品))

無水硫酸ナトリウム：和光純薬製（残留農薬分析用）

$\mathrm{KOH}$, 濃硫酸：和光純薬製（特級）

GPC ゲル：BIO-RAD 製（Bio-Beads S-X3）

フロリジル：和光純薬製 (Florisil PR (60１00mesh))

2. 2. 2 トキサフェン

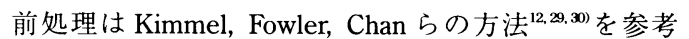
にした。室温で解凍した脂皮試料約 $1 \mathrm{~g}$ にクリーンアッ プスパイク (Trans-Chlordane ${ }^{-{ }^{13}} \mathrm{C}_{10}$ ) を添加し, アセトン ノヘキサン $=1: 2$ の混合溶液でホモジナイズ抽出した。 抽出液を遠心分離し残渣を除去した後, 純水を加え液液 抽出した。へキサン層を分取し無水硫酸ナトリウムで脱 水後, 数 $\mathrm{m} \ell$ まで減圧濃縮した液をアセトニトリル $/$ キサン分配法もしくはゲル浸透クロマトグラフィー（移 動相：ヘキサンノジクロロメタン $=1: 1$ 混合液）法で 脱脂した。さらに処理液を数 $\mathrm{m} \ell$ まで減圧濃縮した後, 活性化（予め $130^{\circ} \mathrm{C}$ で15時間加熱し，デシケータ中で放 冷）したフロリジルカラムでクリーンアップ（溶出液： $5 \%$ \%エチルエーテル／へキサン混合液）を行った。 溶出液を $0.5 \mathrm{~m} \ell$ まで減圧濃縮した後, シリンジスパイク $\left[2,2\right.$ ', 4, 5, 5'-Pentachloro $\left[{ }^{13} \mathrm{C}_{12}\right]$ biphenyl (PCB \# 101${ }^{13} \mathrm{C}_{12}$ ), 2, 2', 3, 3', 4, 4', 5-Heptachloro $\left[{ }^{13} \mathrm{C}_{12}\right]$ biphenyl (PCB $\left.\# 170{ }^{-13} \mathrm{C}_{12}\right)$ ] を添加し, 最終溶液とした。

トキサフェンは四重極型ガスクロマトグラフ質量分析 計（HRGC-LRMS）を用いて，一般的に利用されている $\mathrm{EI}$ 法より高選択性, 高感度な負イオン化学イオン化 （NCI）法で, 選択イオン検出（SIM）モードにより測定 した。保持時間及び 3 つ測定イオンの強度比により同 定し, 内部標準法により定量した。本研究では, 生物種 への残留性が高いため欧米諸国の研究者が指標として推

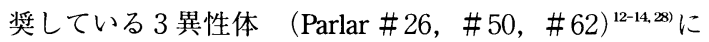
加え, 製剤中の含有量が比較的高い2 異性体 (Parlar \# 32, \#69）の計 5 異性体を分析対象とした。以後, 対象 としたトキサフェンの 5 異性体をそれぞれ P26, P32, P50，P62，P69と略して表記する。それらの構造を Fig. 2 に，測定条件の詳細を Table 2 に, SIM モードのモ ニターイオンを Table 3 に示す。

装置検出下限 (IDL) は, S/N 比 $5 \sim 15$ 程度の濃度の標 準液を 5 回繰り返し測定し, 得られた測定值から標準偏 差を求め, その 2 倍（ $\mathrm{t}$ 検定值片側, 危険率 $5 \%$ ）の濃度 とした。測定対象とした 5 異性体の IDL は $0.1 \sim 0.2$ $\mathrm{ng} / \mathrm{m} \ell$ であり, 試料量, 脂肪量, 最終前処理液量, 装置 注入量等から検出下限值を $1 \mathrm{ng} / \mathrm{g}$ lipid wt とした。な お, P32の検出下限值は, 試料の測定における夾雑物の 影響があり, 10ng/g lipid wt とした。

2. 2. 3 マイレックス

前処理は PCBs や他の有機塩素化合物で採用されてい 


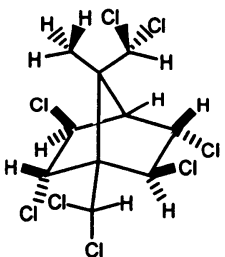

2-endo,3-exo,5-endo,6-exo,8b,8c, 10a, 10cOctachlorobomane

Parlar \#26 (8Cl)

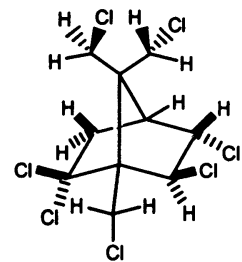

2,2,5-endo,6-exo,8c,9b,10aHeptachlorobornane

Parlar \#32 (7Cl)

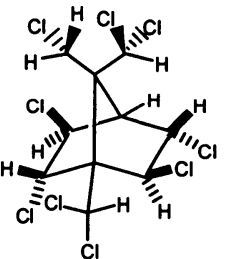

2-endo,3-exo,5-endo,6-exo,8b,8c,9c,10a,10cNonachlorobomane

\section{Parlar \#50 (9Cl)}

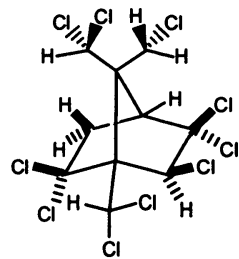

2,2,5,5,6-exo,8c,9b,9c,10a,10bDecachlorobornane

Parlar \#69 (10Cl)



$2,2,5,5,8 c, 9 b, 9 c, 10 a, 10 b$ Nonachlorobornane

Parlar \#62 (9Cl)

1,1a, 2, 2,3,3a, 4,5,5a,5b,6-dodecachloroactahydro-1,3,4-metheno-1H-cyclobuta[cd]pentalene

Mirex

Fig. 2 Chemical structures of representative toxaphene isomers and mirex analyzed in this study

る方法 ${ }^{31)}$ を参考にした。室温で解凍した脂皮試料約 $1 \mathrm{~g}$ にクリーンアップスパイク $[2,2$ ', 4, 5, 5'-Pentachloro $\left[{ }^{13} \mathrm{C}_{12}\right]$ biphenyl $\left.\left(\mathrm{PCB} \# 101-{ }^{13} \mathrm{C}_{12}\right)\right]$ を添加後, $1.5 \mathrm{M}$ $\mathrm{KOH} /$ エタノールを加えて超音波にて 6 時間アルカリ分 解した。分解液及びその洗浄液（アセトン，アセトン／ ヘキサン＝1:1, ヘキサン）を濾過し, 純水を加え液 液抽出した。へキサン層を分取し濃硫酸を加え, 振とう 洗浄した。この硫酸洗浄を硫酸層が無色になるまで繰り 返した後, ヘキサン層を分取し, 純水を加え洗浄した。 分取したへキサン層を無水硫酸ナトリウムで脱水し, 数 $\mathrm{m} \ell$ まで減圧濃縮した後, 活性化したフロリジルカラム でクリーンアップ（溶出液：5\%ジエチルエーテル $/ へ$ キサン混合液) を行った。溶出液を $0.5 \mathrm{~m}$ l まで減圧濃縮

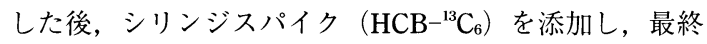
溶液とした。

マイレックスはHRGC-LRMS-EI 法（SIM モード）を 用いて，保持時間及び $3 つ の$ 測定イオンの強度比により 同定し, 内部標準法により定量した。マイレックスの構 造を Fig. 2 に, 測定条件の詳細を Table 2 に, SIM モード 法のモニターイオンを Table 3 に示す。

マイレックスの IDL $(0.9 \mathrm{ng} / \mathrm{m} \ell)$ はトキサフェンと 同様に求め, 試料量, 脂肪量, 最終前処理液量, 装置注 入量等から検出下限值を $2 \mathrm{ng} / \mathrm{g}$ lipid wt とした。

\section{3. 結果と考察}

分析に供した全ての試料からトキサフェン（140～ 6,700ng/g lipid wt) 及びマイレックス（2 170ng/g lipid wt）が検出された（Table 1)。日本では，マイレッ クスが15年以上前に母乳中から検出された例があるの み ${ }^{27)}$ で, 本研究は, 日本周辺で採取した野生生物からこ れらの物質を検出した初めての報告である。

\section{1 トキサフェン}

\section{1.1 污染レベルと暴露経路}

日本近海の鯨類から検出された濃度 $(2,100$ (平均) $\pm 1,900$ (標 準 偏 差) (140（最小） $-6,700$ (最大) ) ng/g lipid wt）は, 欧米諸国等の使用実績があるかもし くは周辺地域の影響を強く受けると考えられる海域に生 息する海棲哺乳類の報告値 4 , 17, 28, 32-36) の範囲内であった (Table 4$)$ 。三陸沖で採取したイシイルカから最高濃度 $(6,700 \mathrm{ng} / \mathrm{g}$ lipid wt) が検出され, 興味深いことに, そ の值は欧米諸国で報告されている鯨類の検出例の中で高 値に相当した。

オス (adult + subadult) から検出されたトキサフェン の残留濃度は鯨種により大きく異なり, 北西太平洋やオ ホーツク海, 日本海の外洋域を回遊しているイシイルカ $(3,700 \pm 1,500 \mathrm{ng} / \mathrm{g}$ lipid wt $)$ やカマイルカ $(4,200 \mathrm{ng} / \mathrm{g}$ 


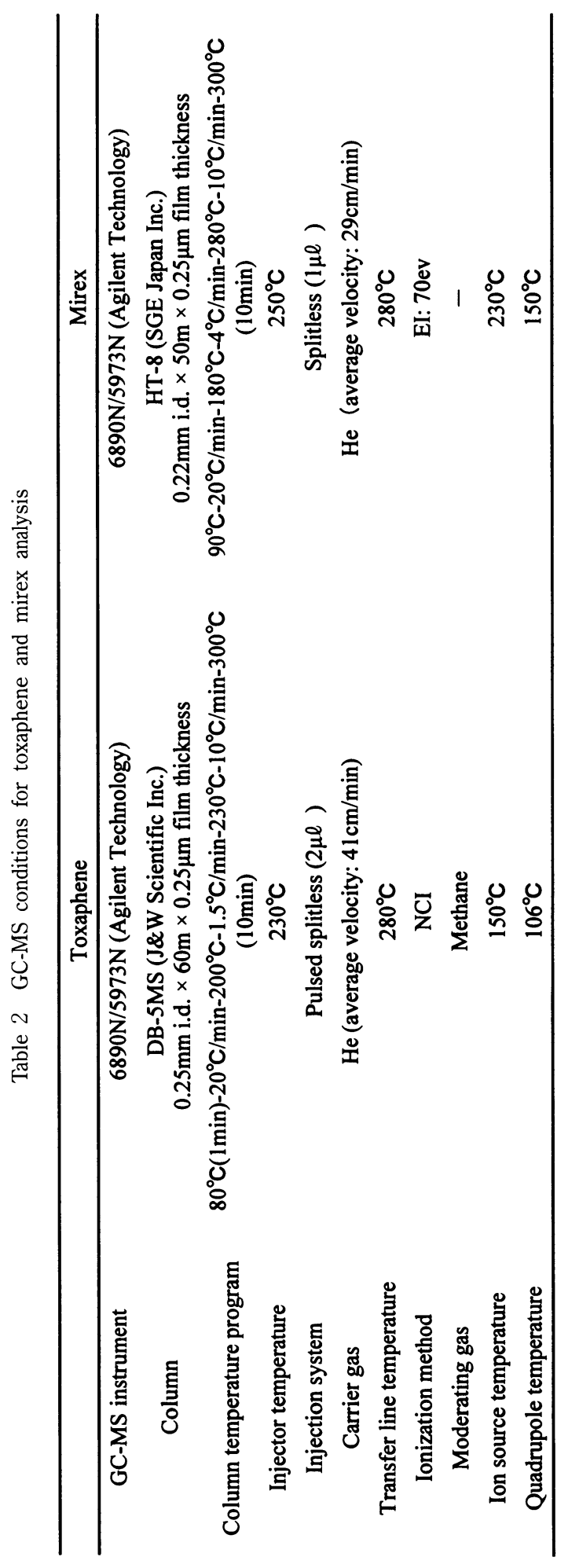

lipid wt）は，沿岸性のスナメリ（250土93ng/g lipid wt） に比べ明らかな高值を示した (Fig. 3 )。このことは, 沿 岸域に生息する鯨類に比べ外洋を広範囲に回遊している 種はトキサフェンの暴露量が多いことを示している。ま た, 日本沿岸の鯨類から検出された濃度は, 鯨類におけ るこれまでの報告值と比べて低值であった。かつてわが 国で多用された PCBs や規制の遅れたクロルデン類の残 留濃度は外洋性鯨類よりスナメリ（沿岸性）で高值を示 すことが報告されている37。以上のことから, 本研究結 果は, 日本でトキサフェンの農薬としての登録実績がな かったことと矛盾しておらず，イシイルカやカマイルカ は主に回遊ルートである北西太平洋やオホーツク海, 日 本海の污染の影響を受けていることが考えられた。

トキサフェンは, その物理化学的特性から, POPs の 中でも移動拡散性が比較的高いと考えられており, 使用 実績がほとんどない北極域，カナダ，スウェーデン等に おける高濃度污染は, 他地域で使用されたトキサフェン が大気輸送によって運ばれ集積したためとされてい る $^{3.18-21)}$ 。日本周辺の污染海域にトキサフェンが流入する 経路としては, 次の 3つが考えられる。まず始めに, 北 西太平洋, オホーツク海, 日本海の周辺地域にあたる中 国と旧ソビエト連邦は，アジアの中ではトキサフェンの 使用量が多いため 7 .10), これらの海域へ影響を及ぼした 可能性が考えられる。なお, 旧ソビエト連邦は, 中国の 5 倍以上のトキサフェン（10万 $\mathrm{t}$ 以上）を使用したと推 定されており，1992年の段階でも一部使用が認められて いた ${ }^{7.38)}$ 。回遊ルートが異なる 2 つイシイルカ個体群 間でトキサフェン濃度の差が明瞭でなかった（Table 1) ことから, 日本海側と太平洋側の暴露量は同程度である ことが推察された。これまでのイシイルカを対象とした 研究で, DDTs や HCHs などの POPs は, 中国やシベリア 等からの影響を受けているため, 日本海側の流入量が太 平洋側を上回ると考えられている ${ }^{390}$ 。従って, 本研究結 果からは, 中国や旧ソビエト連邦由来のトキサフェンが 日本海へ有意な污染をもたらしたことを明確にできな かった。

二つ目として，アジア中南部地域で使用されたトキサ フェンが北部北西太平洋等の高緯度冷水海域に長距離大 気輸送され, 当該海域に生息する海棲生物の暴露源と なった可能性が考えられる。 HCHs など一部の POPs は その発生源と考えられている低緯度地域に比べ中～高緯 度地域で高い濃度を示すことが知られており, 地球規模 での揮散と沈降を繰り返しながら移動する“グラスホッ パー効果”で説明されている ${ }^{42,43)}$ 。インド等の低緯度地 域で使用された HCHs は大気によって北極域や北部北太 平洋に輸送されることが報告されている ${ }^{41)}$ 。綿花栽培が 盛んなインドのトキサフェン使用量は中国より多いと推 定されており (10万 $\mathrm{t}$ 以下), フィリピン等の他の南部ア 
Table 3 Monitored ions in mass for toxaphene and mirex analysis

\begin{tabular}{|c|c|c|c|c|}
\hline Compound name & $\mathrm{Cl}$ number & Quantification ion & Identification ion 1 & Identification ion 2 \\
\hline P26 & 8 & 378.8 & 376.8 & 374.8 \\
\hline P32 & 7 & 342.8 & 340.8 & 344.8 \\
\hline P50 & 9 & 412.8 & 410.8 & 414.8 \\
\hline P62 & 9 & 412.8 & 410.8 & 414.8 \\
\hline P69 & 10 & 446.7 & 444.7 & 448.7 \\
\hline $\begin{array}{c}\text { Cleanup spike } \\
\text { (Trans-Chlordane- }{ }^{13} \mathrm{C}_{10} \text { ) }\end{array}$ & 8 & 419.8 & 421.8 & - \\
\hline $\begin{array}{c}\text { Syringe spike } \\
\left(\mathrm{PCB} \# 101-{ }^{13} \mathrm{C}_{12}\right)\end{array}$ & 5 & 337.9 & 335.9 & - \\
\hline $\begin{array}{c}\text { Syringe spike } \\
\left(\mathrm{PCB} \# 170-{ }^{13} \mathrm{C}_{12}\right)\end{array}$ & 7 & 405.8 & 407.8 & - \\
\hline Mirex & 12 & 271.8 & 273.8 & 269.8 \\
\hline $\begin{array}{c}\text { Cleanup spike } \\
\left(\mathrm{PCB} \# 101-{ }^{13} \mathrm{C}_{12}\right)\end{array}$ & 5 & 337.9 & 335.9 & - \\
\hline $\begin{array}{l}\text { Syringe spike } \\
\left(\mathrm{HCB}-{ }^{13} \mathrm{C}_{6}\right)\end{array}$ & 6 & 291.8 & 293.8 & - \\
\hline
\end{tabular}

ジア諸国でも使用実績がある7゙。また， $\mathrm{HCHs}$ 等で指摘 されているような違法使用の可能性も考えられる ${ }^{7.37)}$ 。

三つ目の可能性として，トキサフェンの主要な生産・ 使用地域であった米国からの大気輸送が挙げられる。 Li $ら^{18,41)}$ は, カナダ北極圏の大気中トキサフェン濃度の経 年変動から, 北米大陸における主なトキサフェンの発生 源は，米国で最も使用量の多かった南東部地域と推定し ている。さらに南東部地域の土塞中には, 過去に使用さ れたトキサフェン約 3 万 $\mathrm{t}$ が残留しており，そこから年 間数 $100 \mathrm{t}$ が大気中に放出され，今なお大きな発生源に なっていると推定されている ${ }^{18,41)}$ 。米国は世界のトキサ フェン使用量の約40\%（49万t）を占めており ${ }^{41) ， ア シ ゙ ア ~}$ における総使用量7.10.38) よりはるかに多いことを考慮する と, その影響は北米大陸高緯度地域に限らず, 北太平洋 全域に及んでいる可能性がある。米国から北西太平洋へ のトキサフェンの輸送は, 大気経由に加え, カナダの西 部にあたるべーリング海から南下している海流（親潮） の関与も考えられる。

以上のように, 外洋性鯨類が分布している北西太平洋 やオホーツク海, 日本海へのトキサフェンの主な流入源 は中国, 旧ソビエト連邦, 低緯度アジア域, アメリカ合 衆国の 4 地域が考えられ，これらがその污染実態に複雑 に関与していると推察された。こうした污染実態を解明 するには，ダイオキシン類やPCBのように日本国内の みの情報では不十分であり, 様々な環境媒体を通したア ジア全域の時空間的な環境動態の把握が必要と考えられ る。また，発生源を特定するには，トキサフェンの使用 実績に関するアジア諸国の情報収集が今後の重要課題と 考えられた。

\section{1.2 異性体組成}

イシイルカの脂皮とトキサフェン製剤から得られた SIM クロマトグラムを Fig. 4 に示す。製剤からは $6 〜 10$ 塩素化体を中心に多数の成分が検出されたにも関わら ず，鯨類試料中のトキサフェンはきわめて単純なクロマ トパターンを示した。本研究で分析対象とした 5 異性体 のうち，P26，P50，P62は全個体から検出され，特に P26，P50はマスクロマトグラム上で最も残留量の多い 成分であった。一方，製剂中の含有量が比較的多い P32 および P69は, 全個体で検出下限值以下であった（Table 1)。

日本近海の鯨類から検出されたトキサフェンの異性体 組成を Fig. 5 に示す。全ての試料において P26と P50が 全体の約 $90 \%$ を占め, これまでの鯨類における報 告17,28,31,36) と同様であった。鯨類の成熟度や性による組成 の差異は認められなかった。P26と P50の残留組成は鯨 種によって異なり, カマイルカとネズミイルカでは, P50の方がP26よりも多く蓄積していたが，他の三種は 逆の傾向を示した。なかでもオウギハクジラにおける P50の蓄積割合は他種よりも明らかに小さく，本種が深 海で摂餌することと関連している可能性がある。カナダ のセントローレンス河に生息するシロイルカ（Beluga， Delphinapterus leucas）では，P50が P26の約 2 倍を占め, その比に雌雄差のないことが報告されている ${ }^{33,34}$ 。また, 鯨やアザラシのトキサフェン異性体組成は南北半球間で 異なっており，北半球の P50残留比は高いことが報告さ れている ${ }^{40)}$ 。本研究結果はこれらの報告と必ずしも一致 せず,このことはアジア域に固有の暴露ルートがあるこ と，もしくは鯨類によりトキサフェンの蓄積パターンに 特異性があることを示唆している。 


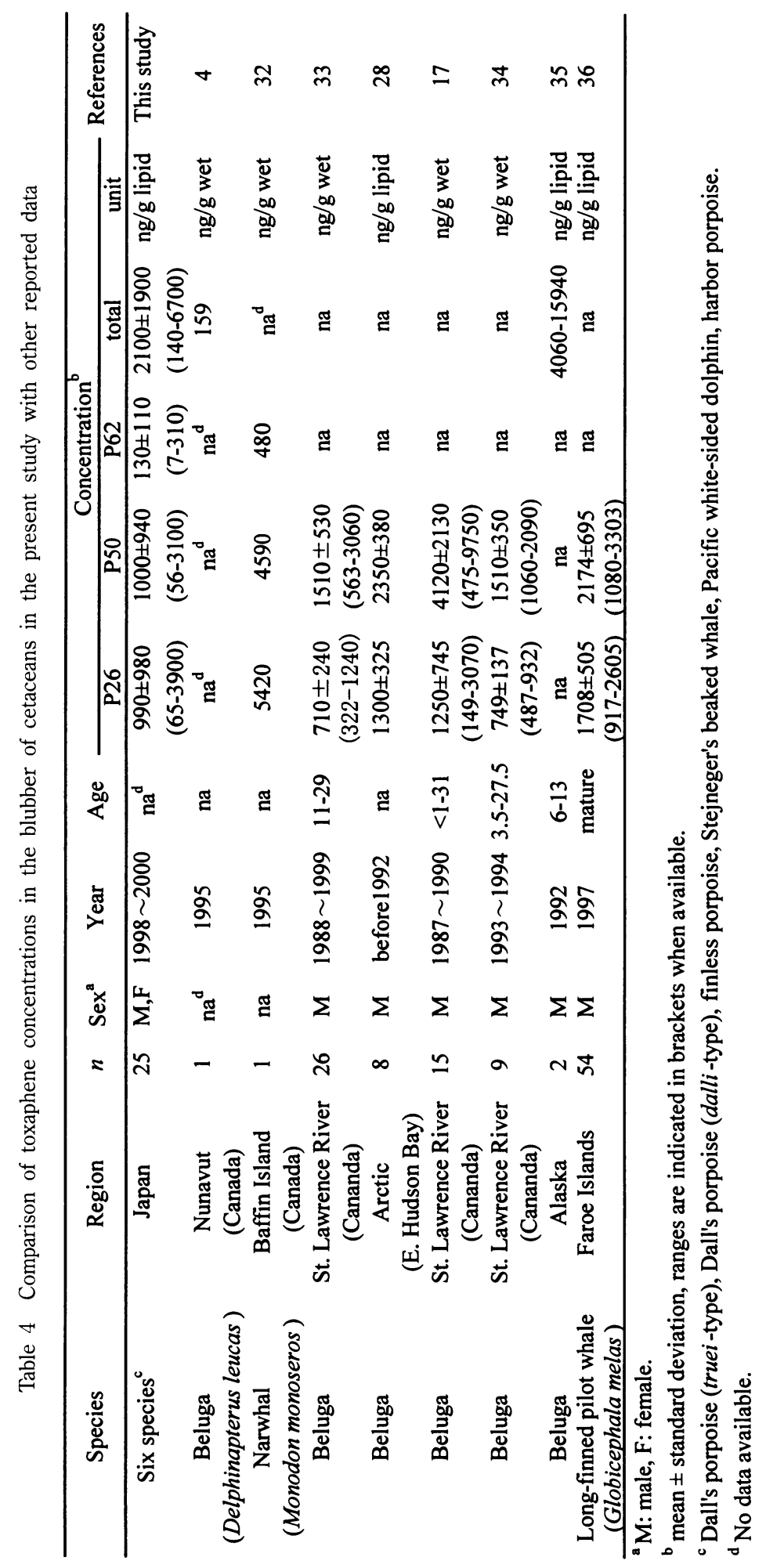




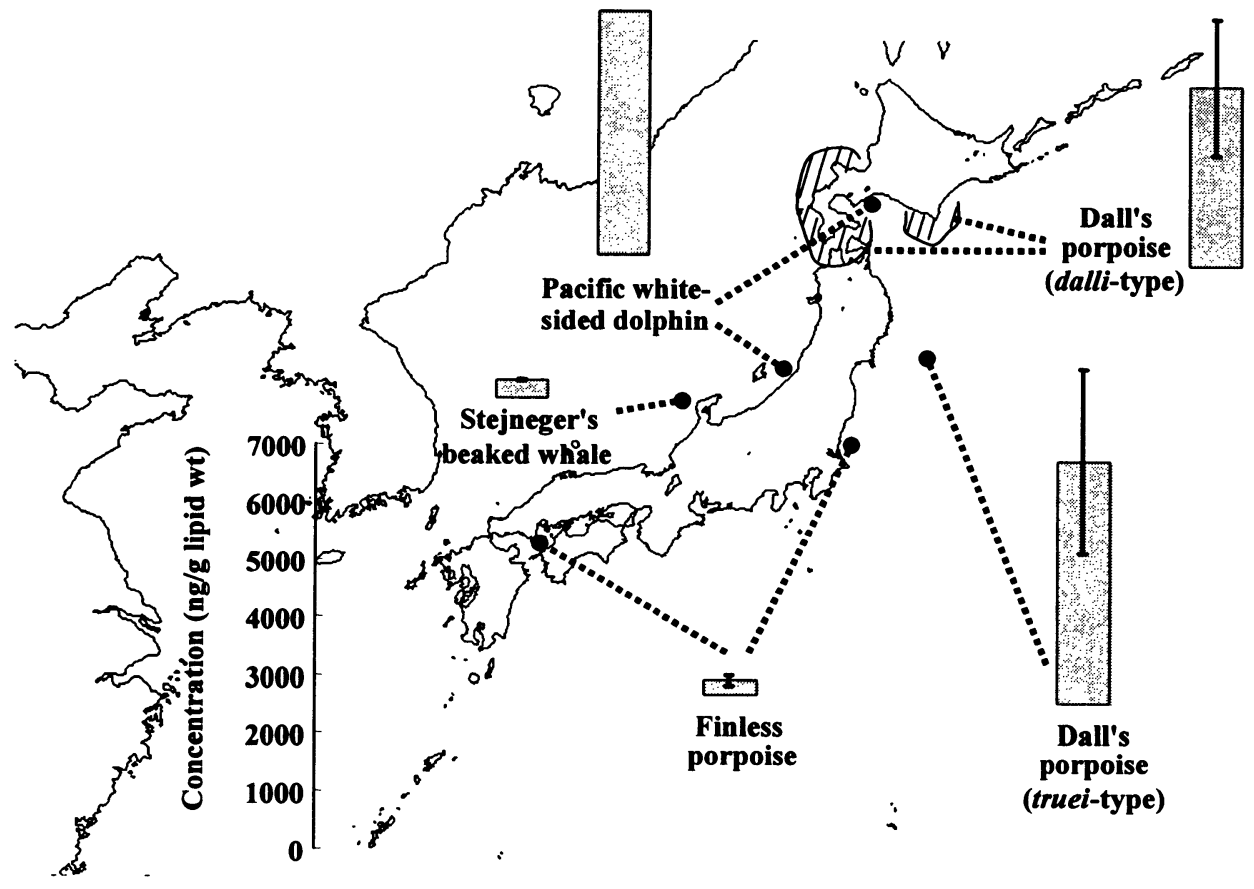

Fig. 3 Comparison of toxaphene residue levels in the blubber of adult and subadult male cetaceans from various locations of Japan

\section{Dall's porpoise}



\section{Technical toxaphene}

$\underline{6 \mathrm{Cl}}$

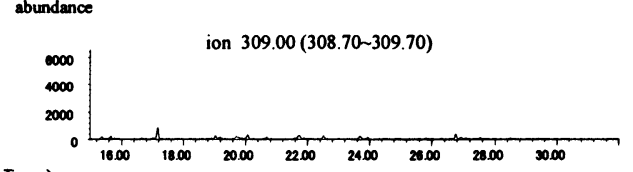

Time-r

abundance $\quad$ ion $343.00(342.70 \sim 343.70)$

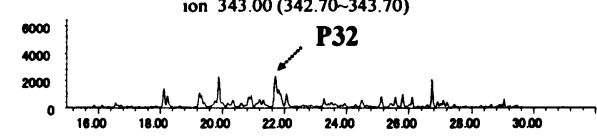

Timo- $\rightarrow$

$\underline{8 \mathrm{CI}}$

abundance ion $379.00(378.70-379.70)$

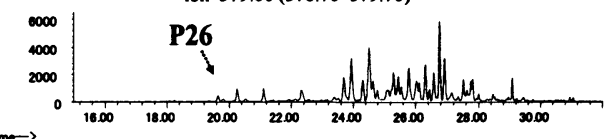

Timo $\rightarrow$

abundance $\quad$ ion $413.00(412.70 \sim 413.70) \quad$ P62

9Cl

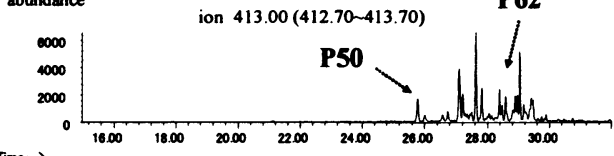

$$
\text { Timo- } \rightarrow
$$

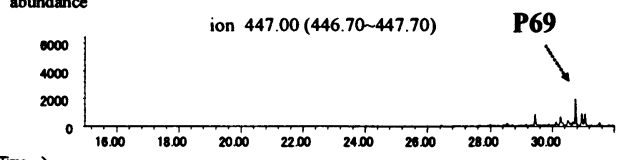

Fig. 4 Comparison of mass chromatograms in the blubber of Dall's porpoise and technical toxaphene mixtures 
$\square$ P26 $\square$ P50 $\triangle \mathrm{P} 62$

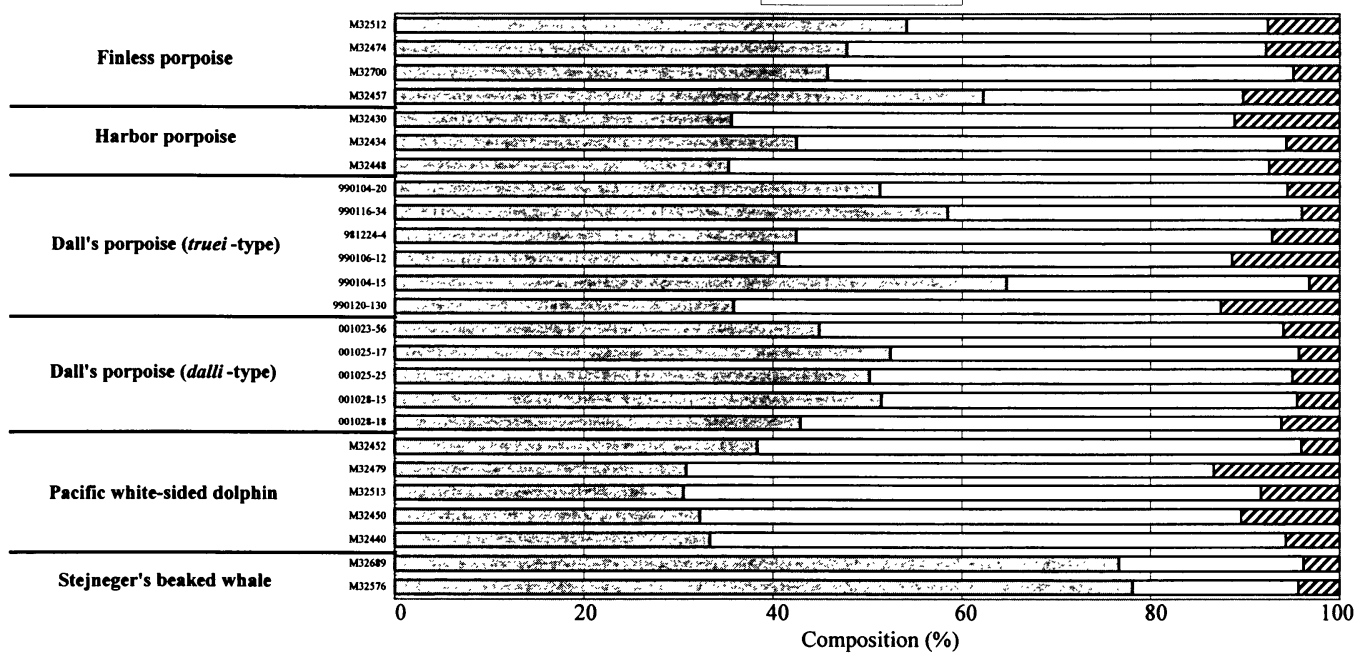

Fig. 5 Percentage compositions of toxaphene isomers in the blubber of cetaceans from various locations of Japan

\section{2 マイレックス}

日本近海の鯨類から検出されたマイレックス濃度 (43 土41( $2 \sim 170) \mathrm{ng} / \mathrm{g}$ lipid wt）は，使用実績がある北米大 陸及びブラジル近海に生息する海棲哺乳類の報告 值 ${ }^{45}$,46.48,49) より低值であったが，周辺諸国の使用実績が不 明なバルト海の報告值年より高值であった（Table 5 )。 トキサフェンと同様に，三陸沖で採取したイシイルカか ら最高濃度 (170ng/g lipid wt) が検出され, 日本で農薬 としての登録実績が無いにも関わらず，これまでに報告 された鯨類の中では比較的高い值を示した。なお，日本 近海鯨類におけるマイレックスの検出濃度はトキサフェ ンの $1 / 50$ 程度であった。

オス (adult + subadult) から検出されたマイレックス の残留濃度を Fig. 6 に示す。トキサフェンと同様にマイ レックスの残留濃度は鯨種により大きく異なり，外洋域 を回遊しているイシイルカ $(65 \pm 46 n g / g$ lipid wt $)$ やカ マイルカ (77ng/g lipid wt) は, 沿岸性のスナメリ（5 $\pm 3 \mathrm{ng} / \mathrm{g}$ lipid wt) に比べ明らかな高值を示した（Table 1)。このことは，沿岸域に生息する鯨種より外洋を広 く回遊している種の方がマイレックスの暴露量は多いこ とを示している。また, 沿岸性の鯨類から検出された濃 度が，鯨類の報告例の中で最も低い值を示したことは， 日本でのマイレックスの使用が基本的にはなかったこと を裏付けている。以上のことから，イシイルカやカマイ ルカから検出された高いマイレックス濃度は, トキサ フェンと同様，主に回遊ルートの外洋域で暴露された結 果と考えられた。

POPs の中でマイレックスは相対的に蒸気圧及び水へ
の溶解度が低いため，大気を経由した移動拡散性が小さ いことに加え，安定性及び粒子への吸着性が高いことか ら， HCHs やトキサフェンに比べ発生源周辺に留まりや すいと考えられている2 ${ }^{22,43)}$ 。本研究結果より，マイレッ クスは北部北西太平洋やオホーツク海, 日本海などの外 洋域に比較的高濃度に残留していると考えられるが，周 辺諸国における使用実績は不明である。日本の外洋性鯨 類のマイレックス残留濃度が，北米大陸周辺に生息して いる鯨類 $55,46,48)$ の $1 / 10$ 程度であることを考慮すると，大量 使用地域であった北米大陸からの大気輸送及び海流輸送 の影響も考えられる。なお，中南部アジア地域でのマイ レックスの使用実績は不明であるが，トキサフェンで示 唆されたグラスホッパー効果による高緯度冷水域への大 気輸送の影響も否定できない。

以上のことから，日本周辺海域で採取された鯨類のマ イレックス污染経路はトキサフェンと同様, 広域かつ複 雑であることが示唆された。マイレックスの污染経路の 実態を解明するには，トキサフェンと同様，アジア全域 における使用実態並びに環境動態の把握が必要である。

\section{4. まとめ}

日本近海に生息する鯨類が，日本での使用実績がない と考えられているトキサフェンならびにマイレックスに 污染されていることを初めて明らかにした。トキサフェ ンは鯨類を含む生物種の報告例と同様, P26と P50が優 占して残留していたが，種による組成の差異が認めら れ，これまでの鯨類の報告結果とは必ずしも一致しな 


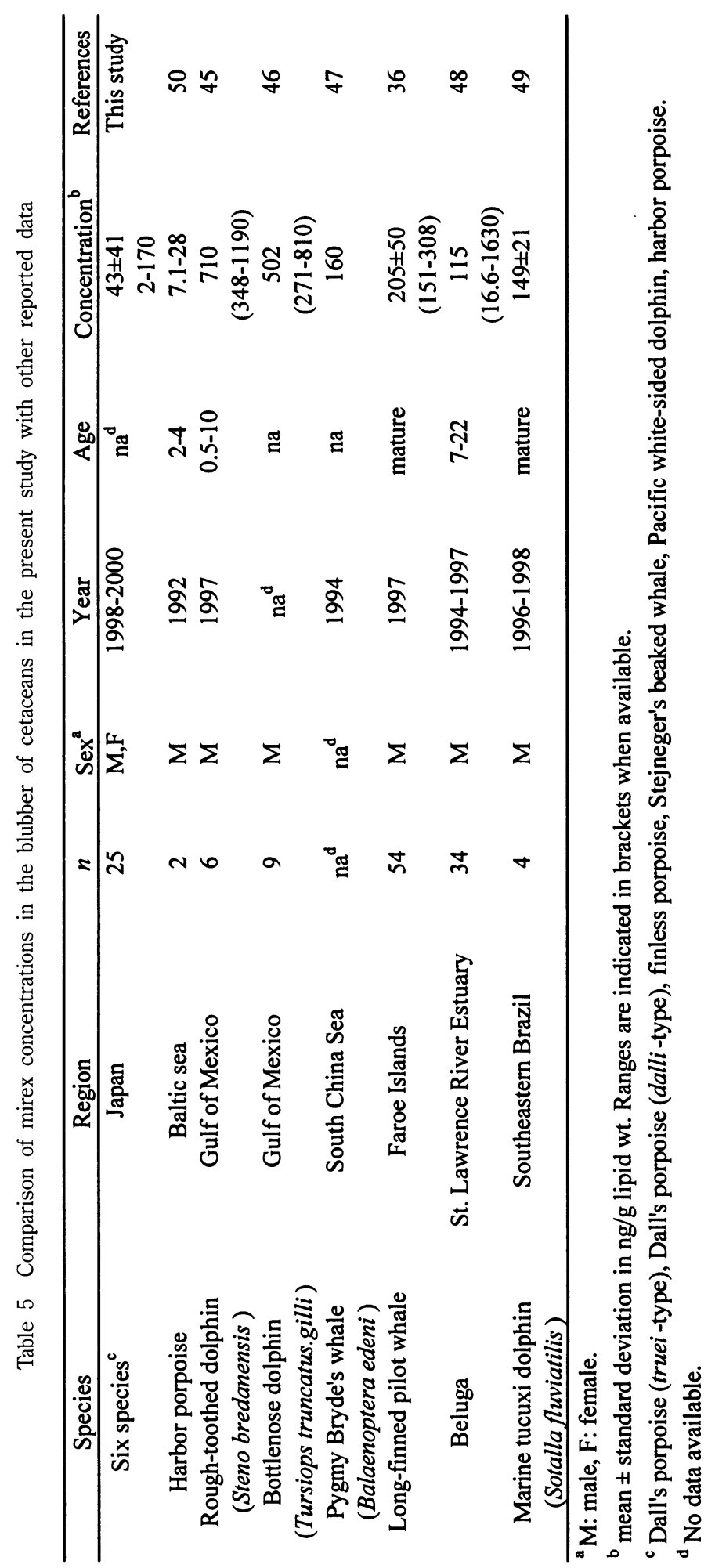




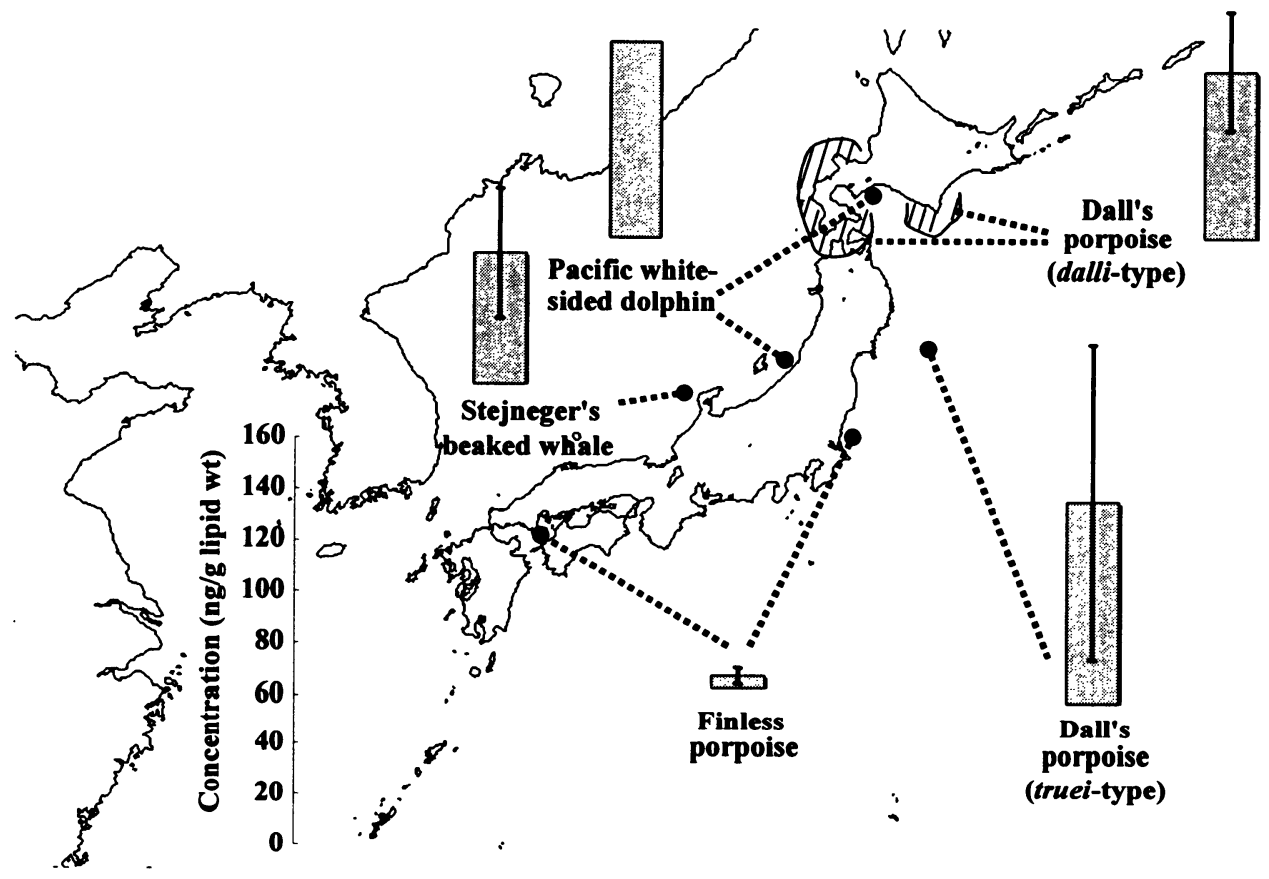

Fig. 6 Comparison of mirex residue levels in the blubber of adult and subadult male cetaceans from various locations of Japan

かった。マイレックスの残留濃度は世界の鯨類データの 中では低值に相当し，トキサフェンより約50倍低い。一 方, トキサフェンの残留濃度は, 周辺地域でその使用の 影響を受けたと考えられる報告值の範囲内であった。ま た，一部の鯨種のトキサフェン残留濃度は，世界的にも 高い值に相当することから, その暴露ルートの解明が重 要と考えられた。2つの物質はどちらも鯨種による污染 レベルの差異は大きく, PCBsやクロルデンとは逆に, 外洋性種は沿岸性種に比べ明らかに濃度が高く, その回 遊海域で暴露の影響を受けたと考えられた。また，沿岸 性種のトキサフェンならびにマイレックスの残留濃度は 世界的にみて低い值であったことは，この薬剤が日本で 使用されなかったことを反映している。

外洋性種がトキサフェンの暴露を受けたと考えられる 海域 (日本海, オホーツク海, 北部北西太平洋) の污染 源として, 中国, 旧ソビエト連邦，低緯度アジア域，ア メリカ合衆国の 4 地域が考えられ，北米大陸同様，アジ ア域でも長距離大気輸送が主要な暴露経路と推察され た。しかしながら，アジアにおけるトキサフェンの環境 動態に関する知見は皆無で，正確な使用地域も不明なた め, 污染源の特定には至らなかった。同海域での暴露を 受けたと考えられるマイレックスは，トキサフェンと物 性が異なるものの, 広域かつ複雑な污染実態を示した。

以上, 本研究では, 日本近海に生息する鯨類のトキサ
フェンとマイレックスの污染実態を解明した。今後は他 の POPs 同様，アジア全域における時空間的な環境動態 を解明することが課題である。

\section{謝 辞}

本研究を実施するにあたり，試料の収集ならびに情報 提供などにご尽力いただいた関係機関, 組織（茨城県立 自然博物館, 柏崎市立博物館, KK エルム, 国立科学博 物館, 下関市立しものせき水族館 - 海響館, 上越市立水 族博物館, 東京大学海洋研究所国際沿岸海洋研究セン ター，常磐大学，のとじま臨海公園水族館，のとふれあ いセンター, 北海道大学, 酪農学園大学), 協力してい たたいた研究者・専門家各位（天野雅男氏，石井悦子氏， 桶田俊郎氏，木村博明氏，国府田良樹氏，斉藤 豊氏， 坂井恵一氏，中原史生氏，中村耕司氏，中村幸弘氏，早 野あづさ氏，的場洋平氏，箕輪一博氏）および鯨類のス トランディングに対応していただいた皆様に心よりお礼 申し上げます。

\section{要 約}

分析に供した全25検体の鯨類試料からトキサフェン及 びマイレックスを検出し，わが国周辺の海洋污染を初め 
て明らかにした。どちらの物質も, 日本からの放出の影 響は認められない一方, 外洋性種は回遊海域の日本海や オホーツク海, 北部北西太平洋で暴露を受けていること が示唆された。とくにトキサフェンの暴露量は多いこと が示唆され, 污染経路として大気が重要な役割を果た し, 広域かつ複雑な影響を及ぼしていることが考えられ た。この海域の污染源として中国, 旧ソビエト連邦, 低 緯度アジア, 米国の 4 地域の可能性が考えられたが, ア ジア域に扔けるこれら物質の使用実績に関する知見が不 足しているため, 特定には至らなかった。本研究の結果 は, アジアにおけるトキサフェンおよびマイレックスの 污染が軽視できないことを示唆しており, 時空間的な環 境動態の把握が今後の課題となった。

\section{文 献}

1) Vetter, W. and Luckas, B.: Theoretical aspects of polychlorinated bornanes and the composition of toxaphene in technical mixtures and environmental samples. Sci. Total Environ., 160/161, 505-510 (1995)

2) Coelhan, M. and Parlar, H.: The nomenclature of chlorinated bornanes and camphenes relevant to toxaphene. Chemosphere, 32, 217-228 (1996)

3) Saleh, M.A.: Toxaphene: chemistry, biochemistry, toxicity and environmental fate. Rev. Environ. Contam. Toxicol., 118, 1-66 (1991)

4) Braekevelt, E., Tomy, G.A. and Stern, G.A.: Comparison of an individual congener standard and a technical mixture for the quantification of toxaphene in environmental matrices by HRGC/ ECNI-HRMS. Environ. Sci. Technol., 35, 3513-3518 (2001)

5) Voldner, E.C. and Schroeder, W.H.: Modeling of atmospheric transport and deposition of toxaphene into the Great Lakes ecosystem. Atmos. Environ., 23, 1949-1961 (1989)

6) Schmitt, C., Ludke, J. and Walsh, D.: Organochlorine residue in fish: National pesticide monitoring program. Pestic. Monit. J., 14, 136-206 (1981)

7) Voldner, E.C. and Li, Y.F.: Global usage of toxaphene. Chemosphere, 27, 2073-2078 (1993)

8) Hopper, N.K., Ames, B.N., Saleh, M.A. and Casida, J.E.: Toxaphene, a complex mixture of polychloroterpenes and a major insecticide, is mutagenic. Science, 205, 591-593 (1979)

9) Reuber, M.D.: Carcinogenicity of toxaphene: a review. J. Toxicol. Environ. Hlth., 5, 729-748 (1979)

10) Voldner, E.C. and Li Y.F.,: Global usage of selected persistent organochlorines. Sci. Total Environ., 160/161, 201-210 (1995)

11）高澤嘉一, 柴田康行, 森田昌敏：トキサフェンの環 境動態とガスクロマトグラフィー/質量分析法によ る定量, 環境化学, 13，343-367 (2003)

12) Kimmel, L., Angerhofer, D., Gill, U., Coelhan, M. and Parlar, H.: HRGC-ECD and HRGC-ECNI-SIMHRMS quantification of toxaphene residues by six environmentally relevant chlorobornanes as standard. Chemosphere, 37, 549-558 (1998)

13) Alder, L., Bache, K., Beck, H. and Parlar, H.: Collaborative study on toxaphene indicator compounds chlorobornanes in fish oil. Chemosphere, 35, 13911398 (1997)

14) Oetjen, K. and Karl, H.: Levels of toxaphene indicator compounds in fish meal, fish oil and fish feed. Chemosphere, 37, 1-11 (1998)

15) Glassmeyer, S.T., de Vault, D.S., Myers, T.R. and Hites, R.A.: Toxaphene in Great Lakes fish: a temporal, spatial, and trophic study. Environ. Sci. Technol., 31, 84-88 (1997)

16) Braune, B., Muir, D., DeMarch, B. Gamberg, M., Poole, K., Currie, R., Dodd, M., Duschenko, W., Eamer, J., Elkin, B., Evans, M., Grundy, S., Hebert, C., Johnstone, R., Kidd, K., Koenig, B., Lockhart, L., Marshall, H., Reimer, K., Sanderson, J. and Shutt, L.: Spatial and temporal trends of contaminants in Canadian Arctic freshwater and terrestrial ecosystems: a review. Sci. Total Environ., 230, 145-207 (1999)

17) Muir, D.C.G., Ford, C.A., Rosenberg, B., Norstrom, R.J., Simon, M. and Beland, P.: Persistent organochlorines in beluga whales (Delphinapterus leucas) from the St Lawrence River estuary-I. Concentrations and patterns of specific PCBs, chlorinated pesticides and polychlorinated dibenzo- $p$-dioxins and dibenzofurans. Environ. Pollut., 93, 219-234 (1996)

18) Li, Y.F. and Bidleman, T.F.: Toxaphene in the United States 2. Emissions and residues. J. Geophys. Res., 106-D16, 17929-17938 (2001)

19) Jantunen, L.M.M., Bidleman, T.F., Harner, T. and Parkhurst, W.J.: Toxaphene, chlordane, and other organochlorine pesticides in Alabama air. Environ. Sci. Technol., 34, 5097-5105 (2000)

20) James, R.R. and Hites, R.A.: Atmospheric transport of toxaphene from the Southern United States to the Great Lakes region. Environ. Sci. 
Technol., 36, 3474-3481 (2002)

21) McDonald, J.G. and Hites R.A.: Radial dilution model for the distribution of toxaphene in the United States and Canada on the basis of measured concentration in tree bark. Environ. Sci. Technol., 37, 475-481 (2003)

22) Ritter, L., Solomon, K.R., Forget, J., Stemeroff, M. and O'Leary, C.: Persistent organic pollutants assessment report. IOMC, Chapter 6 (1995)

23) Environment Canada. Mirex in Canada; Technical Report 77-1; Report of the Task Force on Mirex to the Joint Department of Environment and the National Health and Welfare Committee on Environmental Contaminants. Ottawa, Canada (1977)

24) Environment Studies Board. Kepone/Mirex/ Hexachlorocyclopentadiene, an Environmental Assessment; Panel on Kepone/Mirex/ Hexachlorocy clopentadiene of the Coordinating Committee for Scientific and Technical Assessments of Environmental Pollutants. Washington, DC, National Research Council (1978)

25) Halfon, E.: Error Analysis and simulation behavior in Lake Ontario. National Water Research Institute, Canada Centre for Inland Waters; Burlington, Ontario (1981)

26）環境庁環境保健部環境安全課,「化学物質と環境 (昭和59年度版)」(1985)

27）宮崎泰之, 山岸達典, 松本昌雄 : 母乳中の $1,2,4,5-$ テトラブロムベンゼン及びミレックスの分析法と残 留レベル，食衛誌，28，125-129（1987）

28) Stern, G.A., Muir, D.C.G., Ford, C.A., Grift, N.P., Dewailly, E., Bidleman, T.F. and Walla, M.D.: Isolation and identification of two major recalcitrant toxaphene congeners in aquatic biota. Environ. Sci. Technol., 26, 1838-1840 (1992)

29) Fowler, B.: The determination of toxaphene in environmental samples by negative ion electron capture high resolution mass spectrometry. Chemosphere, 41, 487-492 (2000)

30) Chan, H.M. and Yeboah, F.: Total toxaphene and specific congeners in fish from the Yukon, Canada. Chemosphere, 41, 507-515 (2000)

31）環境庁水質保全局水質管理課, 「外因性内分泌攪乱 化学物質調査暫定マニュアル（水質, 底質, 水生生 物)」(1998)

32) Chan, H.M., Zhu, J. and Yeboah, F.: Determination of toxaphene in biological samples using high resolution GC coupled with ion trap MS/MS. Chemo- sphere, 36, 2135-2148 (1998)

33) Gouteux, B., Lebeuf, M., Muir, D.C.G. and Gagne J-P.: Levels and temporal trends of toxaphene congeners in beluga whales (Delphinapterus leucas) from the St. Lawrence Estuary, Canada. Envion. Sci. Technol., 37, 4603-4609 (2003)

34) Muir, D.C.G., Koczanski, K., Rosenberg, B. and Beland, P.: Persistent orgnochlorines in beluga whales (Delphinapterus leucas) from the St. Lawrence River Estuary-II. Temporal trends, 19821994. Environ. Poll., 93, 235-245 (1996)

35) Wade, T.L., Chambers, L., Gardinali, P.R., Sericano, J.L., Jackson, T.J., Tarpley, R.J. and Suydam, R.: Toxaphene, PCB, DDT, and chlordane analyses of beluga whale blubber. Chemosphere, 34, 1351-1357 (1997)

36) Dam, M. and Bloch, D.: Screening of mercury and persistent organochlorine pollutants in Long-finned Pilot Whale (Globicephala melas) in the Faroe islands. Mar. Pollut. Bull., 40, 1090-1099 (2000)

37）田辺信介, 梶原夏子, 荒金玉美, 渡部真文：日本沿 岸に漂着した鯨類の有機塩素化合物污染とその蓄積 特性, 哺乳類科学増刊号, 3, 83-86 (2003)

38) UNEP Chemicals. Regionally Based Assesment of Persistent Toxic Substances; Central and North East Asia Regional Report. (2002)

39) Kajiwara, N., Watanabe, M., Tanabe, S., Nakamatsu, K., Amano, M. and Miyazaki, N.: Specific accumulation and temporal trends of organochlorine contaminants in Dall's porpoises (Phocoenoides dalli) from Japanese coastal waters. Mar. Pollut. Bull., 44, 1089-1099 (2002)

40) Vetter, W., Klobes, U. and Luckas, B.: Distribution and levels of eight toxaphene congeners in different tissues of marine mammals, birds and cod livers. Chemosphere, 43, 611-621 (2001)

41) Li, Y.F.: Toxaphene in the United States 1. Usage gridding. J. Geophys. Res., 106-D16, 17919-17927 (2001)

42) Mackay, D. and Wania, F.: Transport of contaminants to the Arctic: partitioning, processes and models. Sci. Total Environ., 160/161, 25-38 (1995)

43) Wania, F. and Mackay, D.: Tracking the distribution of persistent organic pollutants. Environ. Sci. Tech., 30, 390-396 (1996)

44) Prudente, M., Tanabe, S., Watanabe, M., Subramnian, A., Miyazaki, N., Suarez, P. and Tatsukawa, R.: Organochlorine contamination in some odonto- 
ceti species from the North Pacific and Indian Ocean. Mar. Environ. Res., 44, 415-427 (1997)

45) Struntz, W.D.J., Kucklick J.R., Schantz M.M., Becker P.R., McFee W.E. and Stolen, M.K.: Persistent organic pollutants in rough-toothed dolphins (Steno bredanensis) sampled during an unusual mass stranding event. Mar. Pollut. Bull., 48, 164192 (2004)

46) Kuehl, D.W. and Haebler, R.: Organochlorine, organobromin, metal, and selenium residues in bottlenose dolphins (Tursiops truncatus) collected during an unusual mortality event in the Gulf of Mexico, 1990. Arch. Environ. Contam. Toxicol., 28, 494-499 (1995)

47) Parsons, E.C.M., Chan, H.M. and Kinoshita, R.: Trace metal and organochlorine concentrations in a Pygmy Bryde's whale (Balaenoptera edeni) from the South China Sea. Mar. Pollut. Bull., 38, 51-55
(1999)

48) Hobbs, K.E., Muir, D.C.G., Michaud R., Beland, P., Letcher, R.J. and Norstrom, R.J.: PCBs and organochlorine pesticides in blubber biopsies from freeranging St. Lawrence River Estuary beluga whales (Delphinapterus leucas), 1994-1998. Environ. Pollut., 122, 291-302 (2003)

49) Yogui, G.T., Santos, M.C.D.O. and Montone, R.C.: Chlorinated pesticides and polychlorinated biphenyls in marine tucuxi dolphins (Sotalia fluviatilis) from the Cananeia estuary, southeastern Brazil. Sci. Total Environ., 312, 67-78 (2003)

50) Strandberg, B., Strandberg, L., Bergqvist, P.A., Falandysz, J. and Rappe, C.: Concentrations and Biomagnification of 17 chlordane compounds and other organochlorines in Harbor porpoise (Phocoena Phocoena) and Herring from the Southern Baltic Sea. Chemosphere, 37, 2513-2523 (1998) 